\title{
pH-SENSITIVE MATERIALS BASED ON SILICA WITH CHEMICALLY IMMOBILIZED METHYL RED: SYNTHESIS AND PROTOLYTIC PROPERTIES
}

\author{
Chuiko Institute of Surface Chemistry of National Academy of Sciences of Ukraine \\ 17 General Naumov Str., Kyiv,03164,Ukraine,_E-mail: roik_nadya@ukr.net
}

\begin{abstract}
The purpose of this work is to study the possibility of creating hydrolytically and chemically stable pH-sensitive materials using silica as a carrier and an acid-base indicator that changes color when the pH of medium is varied. Synthesis of pH-sensitive materials was carried out by covalent binding of methyl red dye with aminopropylsilica in the presence of 1,1'-carbonyldiimidazole as a coupling agent. The porous structure, the chemical composition of the surface, and the protolytic properties of the synthesized silica materials were characterized by low-temperature adsorption-desorption of nitrogen, quantitative chemical analysis, thermogravimetry, diffuse reflectance electron spectroscopy, pH-metry. It was proved that chemical immobilization of methyl red on the silica surface does not have a significant effect on the porous structure of initial silica: the isotherms of nitrogen adsorption-desorption and pore size distribution curves confirm retention of wide pore size distribution after chemical modification of silica. The content of the acid-base indicator chemically immobilized on the silica surface was determined by quantitative chemical analysis of synthesized materials, as well as by thermogravimetry and diffuse reflectance electron spectroscopy in the ultraviolet and visible regions. It was demonstrated that diffuse reflectance electron spectroscopy can be a reliable method of quantitatively determining an indicator dye chemically grafted to the silica surface. It was proved that chemically grafted dye retains the ability to protonation of tertiary amino group and formation of resonance azonium ion, which is responsible for changing the color of methyl red. It was found that the protonation of methyl red chemically fixed on the silica surface occurs at higher $\mathrm{pH}$ values than for individual indicator dye. Therefore, the color change of grafted dye takes place in less acidic solutions. The proposed synthetic approach can be used to produce regenerable and eco-friendly $\mathrm{pH}$-sensitive materials.
\end{abstract}

Keywords: methyl red, silica, chemical immobilization, $p H$-sensitive material

\section{INTRODUCTION}

$\mathrm{pH}$ indicators are usually weak organic acids or bases that change color in response to a variation of the hydrogen ion concentration. A properly selected acid-base indicator can be used for visual assessment of approximate solution $\mathrm{pH}$. In view of high costs as well as toxic and carcinogenic effects of some $\mathrm{pH}$ indicators, the possibility of their immobilization on solid supports is attractive approach of $\mathrm{pH}$ sensor materials synthesis. Silica supports due to high chemical stability and mechanical strength have promising potential in creation of non-toxic, regenerable, reusable, eco-friendly sensor materials.

Acid-base indicators can be introduced into the silica materials by means of the direct doping in sol-gel synthesis [1-14], impregnation $[15,16]$ or covalent bonding by post-synthetic modification $[17,18]$. In the case of doping strategy, $\mathrm{pH}$ indicator is added to the reaction mixture in the process of sol-gel synthesis and entrapped in the matrix during the polycondensation process. Molecules of $\mathrm{pH}$-sensitive substance are surrounded by a silica framework, which prevents their noticeable elution at contact with solutions and protects them from external environment, providing higher chemical stability. At the same time, silica matrix obtained by sol-gel synthesis supports the transport of small molecules and enables successive response of $\mathrm{pH}$ indicator to analyte presence. Numerous studies confirm the ability of successful regulation of entrapped indicator release and its response to $\mathrm{pH}$ change by variation of structural parameters as well as chemical composition of silica framework prepared by sol-gel method [3, 4, 6-10]. Doping is the most widely used strategy to prepare $\mathrm{pH}$ sensor silica materials due to its obvious advantages such as mild reaction conditions, easy control of the content of entrapped $\mathrm{pH}$ indicator, possibility of direct alteration of chemical and structural properties of silica 
support. Despite of the simplicity of preparation, impregnated $\mathrm{pH}$ sensor materials are rarely used $[15,16]$ as they usually have short term stability. Washout of indicator molecules immobilized on silica carrier via physical absorption causes loose of sensor activity and gives erroneous results. Post-synthetic grafting requires the presence of reactive groups on both the $\mathrm{pH}$ indicator and silica material that makes it more tedious than the other two strategies. However, chemical immobilization is attractive alternative to impregnation or encapsulation within silica framework as assures firm retention of sensor moieties in the surface layer. Covalent bonds formation between receptor element and silica framework excludes washout of dye and provides direct contact of grafted $\mathrm{pH}$ indicator with analyte in the external environment $[17,18]$.

In the present study, we report synthesis of $\mathrm{pH}$-sensitive material consisting of acid-base indicator chemically immobilized on silica surface (Scheme 1).

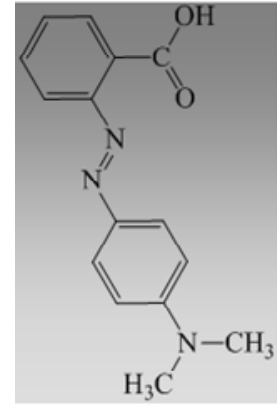

MR

CDI
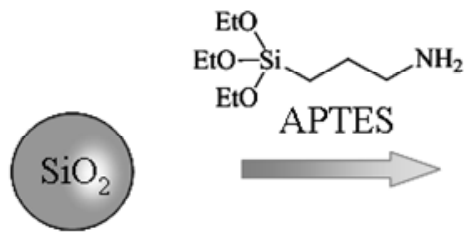

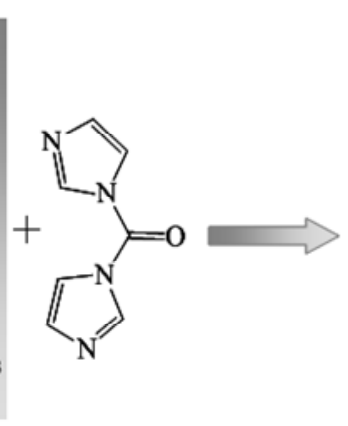

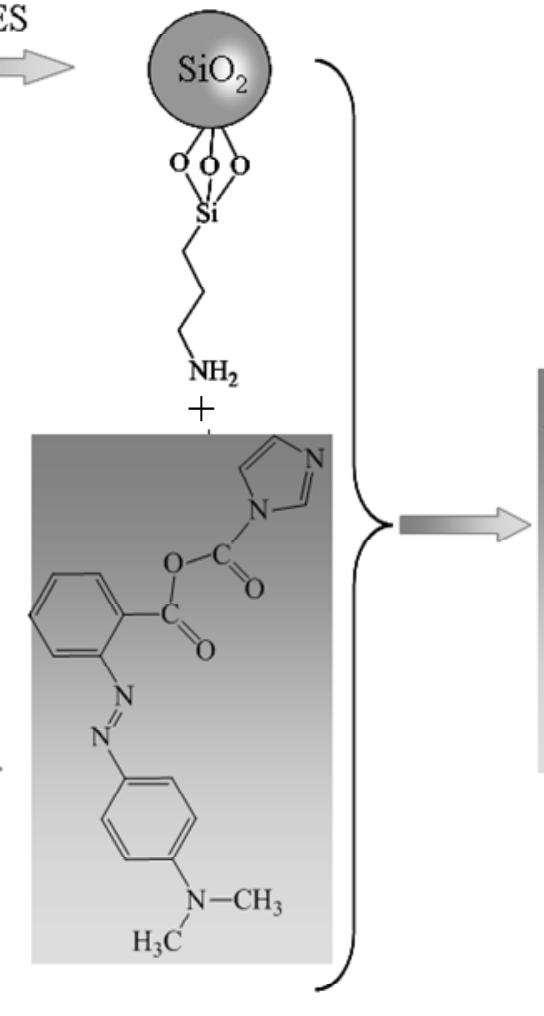
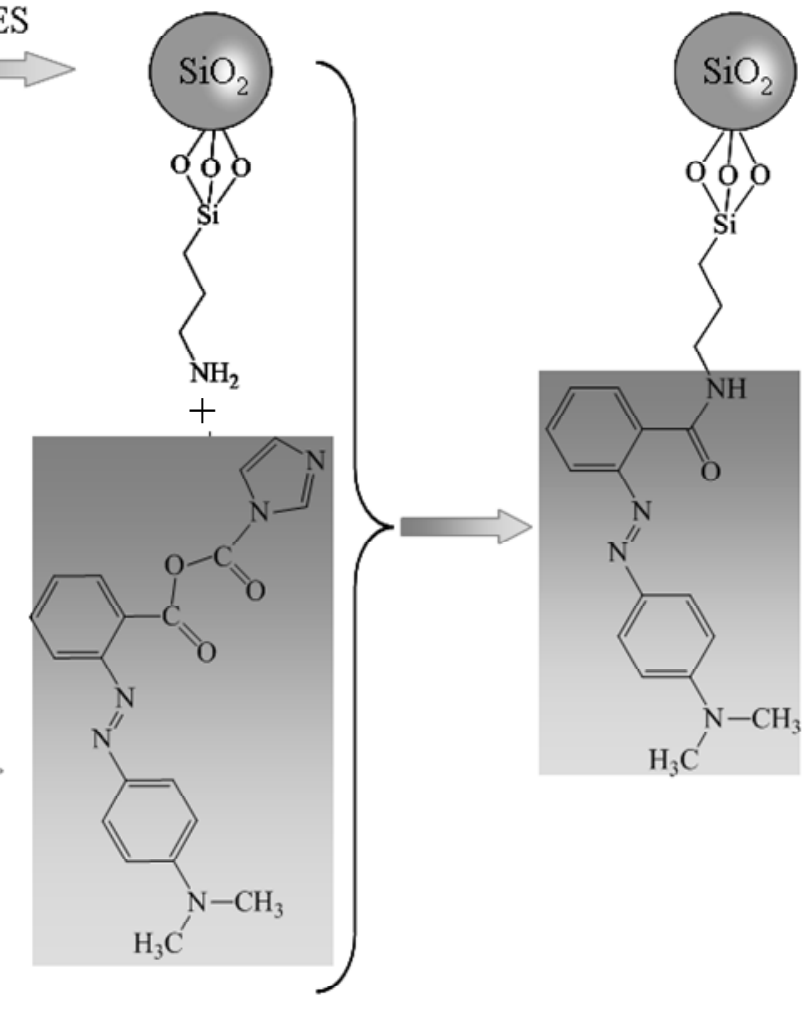

Scheme 1. Chemical immobilization of methyl red on silica surface

At first, aminopropylsilica was synthesized by the reaction between silanol groups of silica surface and ethoxy groups of (3-aminopropyl)triethoxysilane (APTES). Then, grafting of acid-base indicator, methyl red (MR), on aminopropylsilica was realized under mild conditions by use of coupling agent $1,1^{\prime}$-carbonyldiimidazole (CDI). The quantity of MR moieties grafted to the silica support was estimated by quantitative chemical analysis as well as by thermogravimetry and diffuse reflectance ultraviolet-visible (DRUV) spectroscopy. The results obtained were compared to evaluate the usefulness of diffuse reflectance technique to quantitative determination of dye molecules chemically immobilized on silica surface. Acid-base equilibria of surface functional groups were studied by potentiometric titration method, and the ionization constants values were estimated to confirm the ability of synthesized material to $\mathrm{pH}$ response. 


\section{EXPERIMENTAL}

Porous amorphous silica with particles size of $0.315-0.5 \mathrm{~mm}$ was used as starting material. Before chemical modification silica was heated in air at $400{ }^{\circ} \mathrm{C}$ for $2 \mathrm{~h}$ to remove adsorbed water and organic impurities. Concentration of free silanol groups on the surface of pretreated silica was $0.49 \mathrm{mmol} / \mathrm{g}$.

(3-Aminopropyl)triethoxysilane (Merck, purity $\geq 99 \%$ ), 1,1'-carbonyldiimidazole (Merck, purity $\geq 98 \%$ ), methyl red, disubstituted sodium phosphate, monosubstituted potassium phosphate, and phosphoric acid (all from Reakhim, analytical grade), potassium bromide (AppliChem, pharma grade), benzene (Macrochem, analytical grade), sulfuric acid (Reakhim, chemical grade), sodium hydroxide (Macrochem, chemical grade) were used as received without additional purification. Toluene, N,N'-dimethylformamide (DMF), and acetone (all from Reakhim, pure analytical) were dried for $72 \mathrm{~h}$ by use of $4 \AA$ molecular sieves.

Impregnation of MR into silica support. Two series of silica materials containing different amounts of MR were prepared by wetness impregnation. For this, the weighted amounts of aminopropylsilica $(0.5$ and $0.4 \mathrm{~g})$ were placed in glass bottles and wetted with certain volume $(2 \mathrm{ml})$ of $\mathrm{MR}$ solutions in benzene with concentration varying in the range of $\quad 0.043-0.171$ and $1.49-4.47 \mathrm{mmol} / 1$, respectively. The obtained suspensions were thoroughly stirred using shaking water bath at room temperature until complete evaporation of solvent and dried at $100{ }^{\circ} \mathrm{C}$ for $2 \mathrm{~h}$. The resulting products were kept in a desiccator before use (Tables 1, 2).

Chemical immobilization of MR on silica support. Chemical immobilization of MR on silica surface was realized by two-step procedure: synthesis of 3-aminopropylfunctionalyzed silica and modification of its surface with MR in the presence of coupling agent.

Introduction of 3-aminopropyl groups into the surface layer of silica was achieved by the chemical reaction between isolated silanol groups of silica and ethoxy groups of APTES as described in [19]. Briefly, weighted amount of silica $(10 \mathrm{~g})$ preheated at $400{ }^{\circ} \mathrm{C}$ for $2 \mathrm{~h}$ was placed into a three-necked reactor supplied with a stirrer and a reflux condenser, and suspended in a small amount of toluene $(50 \mathrm{ml})$ at room temperature for $40 \mathrm{~min}$, then APTES $(7.05 \mathrm{ml})$ was added. The reaction mixture was stirred at $110^{\circ} \mathrm{C}$ for $6 \mathrm{~h}$. After that the solid phase was transferred on a porous glass filter, washed with toluene until the absence of silane (absence of a violet color with the addition of ninhydrin), then acetone, distilled water (for hydrolysis of the ethoxy groups). The resulting $\mathrm{NH}_{2}-\mathrm{SiO}_{2}$ silica was dried in air at $150{ }^{\circ} \mathrm{C}$ during $6 \mathrm{~h}$.

Immobilization of MR on 3-aminopropylfunctionalyzed silica surface was realized using the activation properties of 1,1'-carbonyldiimidazole. For this, the certain amount of anhydrous MR (0.01616-0.00808 g) was placed in a reactor supplied with an agitator and dissolved in dried DMF $(1 \mathrm{ml})$. Then equimolar amount of CDI $(0.01021-0.0051 \mathrm{~g})$ dissolved in DMF $(1 \mathrm{ml})$ was added dropwise in the reactor while stirring. Activation of MR by condensation of its carboxyl group with CDI was carried out at $20^{\circ} \mathrm{C}$ for $2 \mathrm{~h}$. After that the solution containing $\mathrm{CDI}$-activated $\mathrm{MR}$ was slowly dropped to the suspension of aminopropylsilica in DMF ( $1 \mathrm{~g} / 2 \mathrm{ml}$ of solvent) which was stirred at $20^{\circ} \mathrm{C}$ for $20 \mathrm{~h}$. Thereafter silica material with grafted MR was transferred on a porous glass filter and washed sequentially with DMF and acetone. The air-dried product was washed with benzene, kept at room temperature until complete evaporation of solvent, and dried at $100{ }^{\circ} \mathrm{C}$ for $2 \mathrm{~h}$. Then, it was cooled to room temperature and stored in a desiccator before use (Tables 1,2).

Transmittance $U V$-Vis studies of MR in solutions. Ultraviolet-visible studies of 0.033 and $0.017 \mathrm{mmol} / 1$ solutions of MR in phosphate buffers and benzene, respectively, were carried out over the 200-650 $\mathrm{nm}$ spectral range with a Specord M-40. Quartz cells with $1 \mathrm{~cm}$ pathlength were used.

DRUV studies of MR chemically immobilized and impregnated into silica support. Silica materials with various content of chemically immobilized and deposited MR were used without dilution or mixed with $\mathrm{KBr}$ in the ratio 1:20, ground in a mortar and employed for recording of DRUV spectra over the 350-600 nm spectral range with a Specord M-40 in the optical density mode. To avoid the uncertainties arising from the wide particle size distribution the measurements of the reflectance 
were repeated several times for each sample using the parent silica or its mixture with $\mathrm{KBr}$ in the ratio 1:20 as background. Content of MR chemically immobilized on aminopropylsilica was estimated from calibration curve plotted for a series of aminopropylsilicas with impregnated indicator dye across a range of its contents from 7.45 to $22.35 \mu \mathrm{mol} / \mathrm{g}$.

Thermogravimetry of MR-containing silica materials. Thermogravimetric analysis of synthesized silica materials was carried out on a Perkin Elmer 7 series thermal analyzer. A batch of powdered silica was used for each test. The experiment was performed from ambient temperature to $900{ }^{\circ} \mathrm{C}$ at the heating rate of $10^{\circ} \mathrm{C} / \mathrm{min}$ in open ceramic crucibles in static air atmosphere.

Quantitative chemical analysis of MR-containing silica materials. To evaluate content of MR grafted on aminopropylsilica surface, acid-base hydrolysis of synthesized organosilicas was carried out. Briefly, the batch of MR-containing silica $(0.05 \mathrm{~g})$ was placed in a reactor with a reflux condenser, suspended in a small amount of $\mathrm{H}_{2} \mathrm{SO}_{4}(10 \mathrm{ml}, 1 \mathrm{~mol} / \mathrm{l})$ and refluxed at $100{ }^{\circ} \mathrm{C}$ for $2 \mathrm{~h}$. After that the suspension was cooled to room temperature and neutralized to $\mathrm{pH} \sim 7$ with $\mathrm{NaOH}$ solution. Resulting suspension was mixed with $\mathrm{NaOH}$ solution $(7 \mathrm{ml}, 5 \mathrm{~mol} / \mathrm{l})$, refluxed at $100{ }^{\circ} \mathrm{C}$ for $2 \mathrm{~h}$, cooled to room temperature, neutralized to pH 7.0 and diluted up to $100 \mathrm{ml}$ with water. $\mathrm{pH}$ of solution was precisely controlled with an Ionometer I-120.1. Content of MR in analyzed solution was calculated using the calibration curve fitted in the range of concentrations $1.63-16.3 \mathrm{mmol} / 1$.

Porous structure of MR-containing silica materials. Parameters of porous structure of parent silica and synthesized organosilicas with chemically immobilized MR were obtained from the low-temperature adsorption-desorption of nitrogen at $-196{ }^{\circ} \mathrm{C}$ using a Kelvin-1042 Sorptometer. At first, silica material was outgassed in a vacuum at $140{ }^{\circ} \mathrm{C}$ for $20 \mathrm{~h}$ and then analyzed in the region of relative pressures from 0.06 to 0.99 in increment of 0.015. Specific surface area $\left(S_{\mathrm{BET}}\right)$ was evaluated by the Brunauer-Emmet-Teller method, pore diameter $(D)$ was calculated by the nonlocal density functional theory (NLDFT), and pore volume $\left(V_{\mathrm{p}}\right)$ was determined at $p / p_{\mathrm{o}}=0.95$.
Protolytic properties of MR chemically immobilized on silica support. The potentiometric titration technique was applied to determine the influence of chemical immobilization on MR protolytic properties. For this, the batches of MR-containing silica $(0.5 \mathrm{~g})$ were suspended in $1 \mathrm{M} \mathrm{NaCl}(25 \mathrm{ml})$ to stabilize the system at a given ionic strength. The potentiometric titration of aqueous silica suspensions was started from $\mathrm{pH}$ near 6.5 and performed by stepwise addition of equal volumes $(20 \mu \mathrm{l})$ of titrant $(0.2 \mathrm{M}, 0.4 \mathrm{M}$ or $1 \mathrm{M} \mathrm{HCl})$ with continuous stirring at $20^{\circ} \mathrm{C}$. The equilibrium $\mathrm{pH}$ values of suspensions were measured by an Ionometer I-120.1 that was calibrated for optimal precision using standard buffer solutions of pH 1.68 and $\mathrm{pH}$ 6.86. The equilibrium attainment for each addition of the titrant was estimated by control of the stability of measured $\mathrm{pH}$ value. The apparent constants of ionization were calculated from the potentiometric titration data of MR-containing silica materials using the Henderson-Hasselbach equation $\mathrm{pK}=\mathrm{pH}+\lg [(1-\alpha) / \alpha]$ for $\alpha \rightarrow 0 \quad$ [20]. The potentiometric titration of each sample was repeated at least in triplicate to confirm the results and enhance the accuracy of experiment.

\section{RESULTS AND DISCUSSION}

MR is a well-known indicator dye that has complex acid-base equilibria in the $\mathrm{pH}$ range 2-8 [21]. It changes the color from red (below $\mathrm{pH}$ 3.1) to yellow (over $\mathrm{pH}$ 6.2), between these values of $\mathrm{pH} \mathrm{MR}$ is colored in orange (Scheme 2).

The value of its $\mathrm{pK}_{\mathrm{a} 2}$ is $2.38 \pm 0.05$ at $25^{\circ} \mathrm{C}$ [21], whereas $\mathrm{pK}_{\mathrm{a} 3}$, which corresponds to the equilibrium between neutral and ionized forms of MR, varies from $4.85 \pm 0.01$ to $5.05 \pm 0.05$ in the temperature range $25-30{ }^{\circ} \mathrm{C}$ [21-23]. Covalent bonding of MR on aminopropylsilica surface that proceeds through formation of highly reactive intermediate of MR with CDI and its subsequent conjugation with primary amino groups of silica surface via amide bonds leads to the lost of carboxylic functionality (Scheme 1). Therefore, chemical immobilization of MR on silica support may affect substantially the protolytic properties of acid-base indicator. It was mentioned [10] that MR loses the ability to change color depending on the $\mathrm{pH}$ variation at encapsulation within a silica matrix. As MR has 
two color transitions caused by transition of carboxylic group in the unionized form and protonation of terminal amino group (Scheme 2), involving of carboxylic group into the chemical reaction with 3-aminopropyl functionalities of silica surface should not lead to fully deprive of the $\mathrm{pH}$ sensor properties of chemically immobilized azobenzene dye. It can be supposed that grafted MR will retain the ability for protonation of tertiary amino group and formation of resonance azonium ion which are responsible for the color change at $\mathrm{pH}$ variation. However, the acid-base equilibrium of this process could be shifted in comparison with the initial dye. To confirm this assumption, protolytic properties of silica with chemically immobilized dye moieties were studied.

The transmittance UV-Vis spectra of MR in solutions (Fig. 1) were compared with diffuse reflectance ones of dye chemically immobilized and impregnated into silica support (Figs. 2, 3).

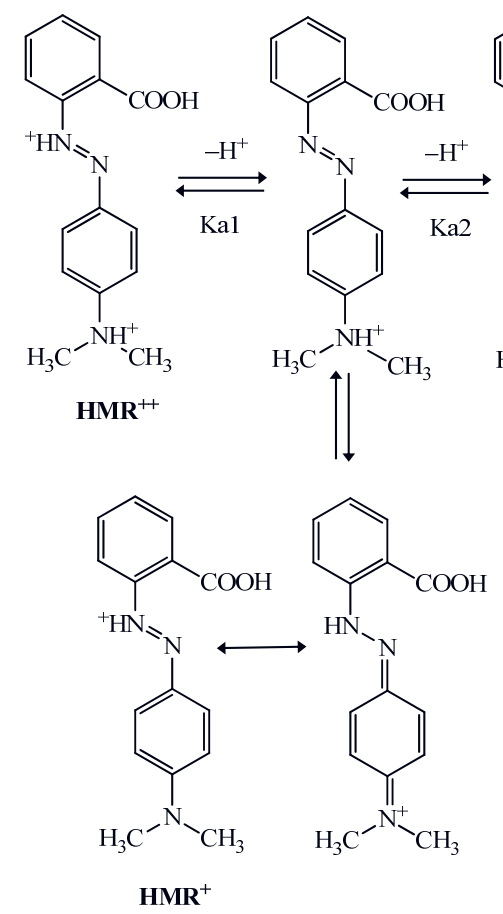<smiles>C=C[Al](C)N(C)c1ccc(N=Nc2ccccc2C(=O)OCc2ccccc2N=Nc2ccc(N(C)C)cc2)cc1</smiles>

Scheme 2. Protolytic equilibria of methyl red [21]

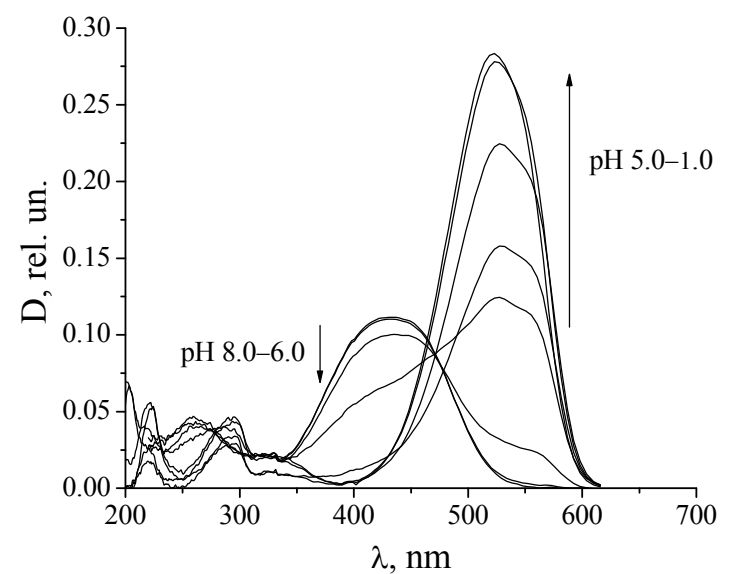

$a$

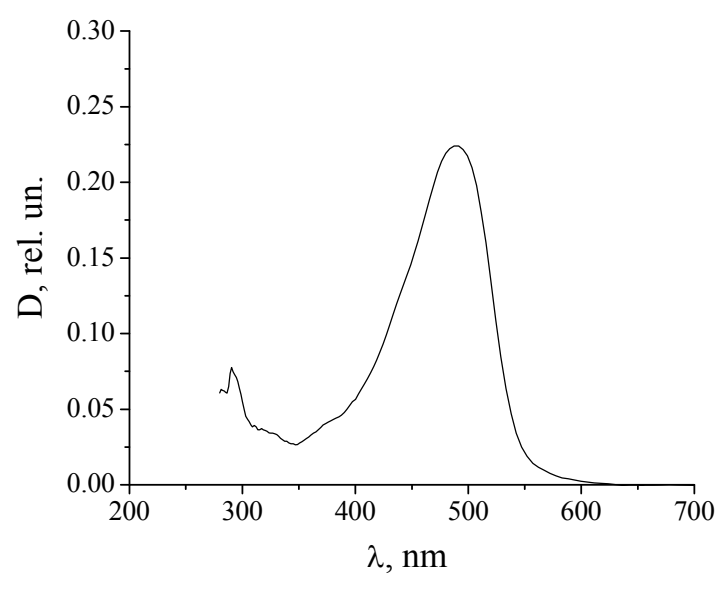

$b$

Fig. 1. Transmittance UV-Vis spectra of MR: $a$ - in phosphate buffer solutions $\left(C_{\mathrm{MR}}=0.0334 \mathrm{mmol} / \mathrm{l}\right) ; b-$ in benzene $\left(C_{\mathrm{MR}}=0.0171 \mathrm{mmol} / \mathrm{l}\right)$ 
As can be seen from Fig. $1 a$, absorption bands at 200, 260, and $428 \mathrm{~nm}$ are observed in the transmittance UV-Vis spectrum of MR in a phosphate buffer solution at $\mathrm{pH}$ 8.0. They are attributed to the benzene rings with carboxylic and amino substituents as well as azo group of azobenzene dye that can be regarded as chromophore. Lowering of $\mathrm{pH}$ value leads to the transformation of MR from its ionized form to the neutral one (Scheme 2). As a result, noticeable reducing of absorption bands intensity in the visible and ultraviolet spectral regions and the bathochromic shift of the low-wavelength absorption peak are observed (Fig. 1a). Moreover, the shoulder around $520-560 \mathrm{~nm}$ imputed to formation of the azonium tautomeric forms of azobenzene dye responsible for the color change starts to appear at $\mathrm{pH} \sim 6.0$. It is known that azo group can exhibit both $n \rightarrow \pi^{*}$ and $\pi \rightarrow \pi^{*}$ excitations. Protonation under acidic conditions leads to the transition of one of the lone pare of azo nitrogens to a bonding state and, as a result, more tight holding of electrons and lowering of molecular orbital levels. So, the bathochromic shift of the absorption peak at $428 \mathrm{~nm}$ to $520 \mathrm{~nm}$ confirms formation of MR form of indicator dye. Positions of highwavelength absorption maxima of MR and $\mathrm{HMR}^{+}$forms of indicator dye are close to each

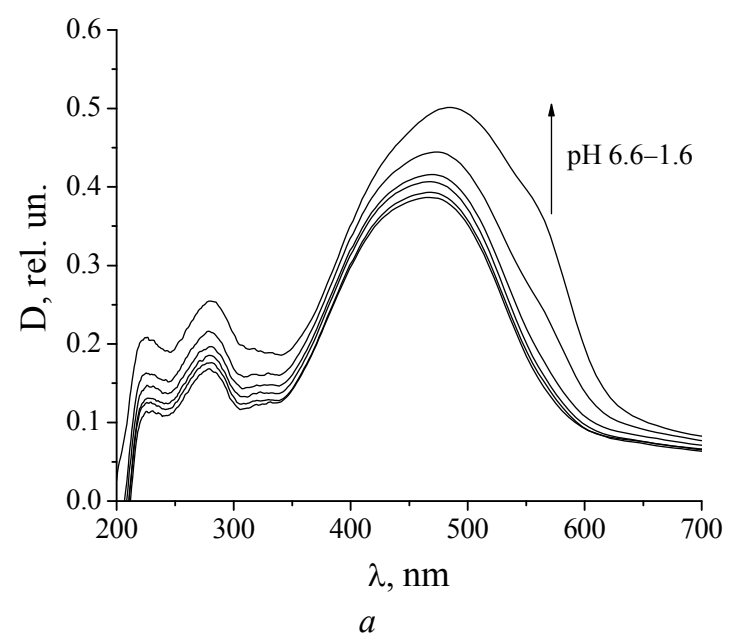

other, therefore in acid medium they are merged together into the strong band around $520 \mathrm{~nm}$. In addition, the bathochromic shift of absorption band at $260 \mathrm{~nm}$ to $291 \mathrm{~nm}$ caused by $n \rightarrow \pi^{*}$ transition of the amino group where lone pair is delocalized and contributes to the resonance structures of the azonium tautomers is observed (Fig. 1 a). As the whole, acidification of aqueous solution leads to the subsequent color change of MR from yellow to orange and red.

UV-Vis spectra of acid-base indicators are often sensitive to polarity of environment as solvent alters the electronic energy levels of chromophore [24]. In the spectrum of MR solution in benzene (Fig. $1 b$ ) the distinct absorption band with maximum near $489 \mathrm{~nm}$ belonging to the $n \rightarrow \pi^{*}$ transition of the $-\mathrm{N}=\mathrm{N}-$ group is registered. Hydrophobic benzene environment causes noticeable bathochromic shift of this absorption band in comparison with its position in phosphate buffer solution with $\mathrm{pH}=6.0-7.0$.

Silica surface effect on the electronic structure of azobenzene dye is clearly seen by comparing the DRUV spectra of MR grafted on aminopropylsilica with transmittance ones registered in phosphate buffer solutions of dye (Figs. 1, 2).

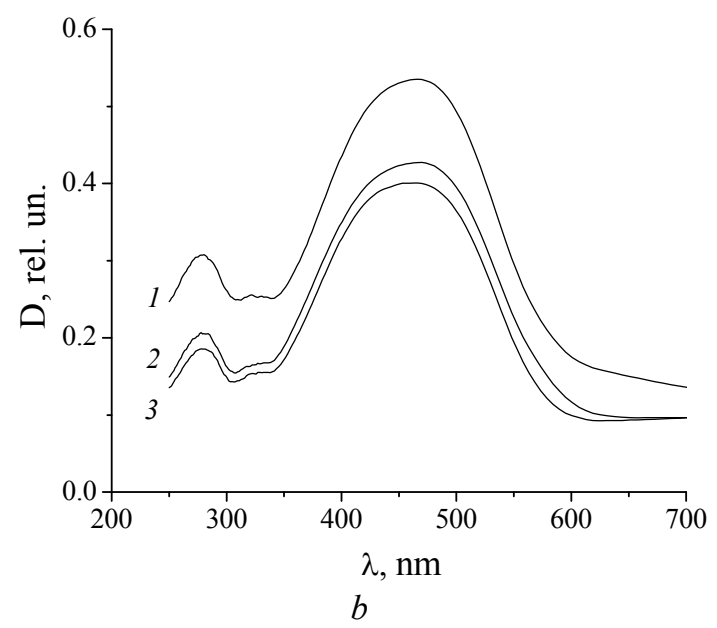

Fig. 2. DRUV spectra of $\mathrm{MR}-\mathrm{SiO}_{2}$ silicas diluted in a 1:20 ratio with $\mathrm{KBr}$ powder: $a$ - 3-MR- $\mathrm{SiO}_{2}$ rinsed with phosphate buffer solutions with different acidity; $b-1-\mathrm{MR}-\mathrm{SiO}_{2}(1), 2-\mathrm{MR}-\mathrm{SiO}_{2}(2), 3-\mathrm{MR}_{-}-\mathrm{SiO}_{2}$ (3) rinsed with benzene $(b)$

The DRUV spectra of MR chemically immobilized on silica surface exhibit three distinct peaks in the visible and ultraviolet spectral regions. However, their positions are slightly different from their positions in the spectra of MR in solutions with the same values of $\mathrm{pH}$ (Figs. 1, $2 a$ ). Obviously, grafting of MR on silica surface through amide bond formation 
causes the electron density redistribution and alteration of molecular orbital levels in chemically immobilized dye. In particular, amide bond forms resonance structure that pulls the electron density away from the azobenzene ring. Its electron withdrawing resonance effect is stronger than that occurring in carboxylic group of MR. Therefore, bathochromic shift of the reflection band belonging to the $n \rightarrow \pi^{*}$ transition of the surface azonium group is less pronounced than that in the case of individual azobenzene dye at solution acidification. At the same time, negative resonance effect of amide group decreases the contribution of amino group with electron pair delocalized in azobenzene rings. As a result, position of absorption band registered at $291 \mathrm{~nm}$ in the transmittance UV-Vis spectra of MR is shifted to $279 \mathrm{~nm}$ for $3-\mathrm{MR}-\mathrm{SiO}_{2}$. In addition, increase in optical density of all absorption bands and bathochromic shift of chromophore band are observed upon $\mathrm{pH}$ rise (Fig. $2 a$ ). The appearance of the shoulder around $550 \mathrm{~nm}$ in the spectra of $3-\mathrm{MR}-\mathrm{SiO}_{2}$ silica takes place only in highly acidic medium after rinsing with buffer solutions with $\mathrm{pH} 2.7$ and $\mathrm{pH} 1.6$ (Fig. $2 a$ ). This fact confirms the change of indicator dye protolytic properties as a result of its chemical immobilization on the silica surface: protonation of surface functionalities proceeds at lower $\mathrm{pH}$ as compared with individual MR. So, the color change from orange to red takes place in more acidic solutions.

Rinsing of synthesized $\mathrm{pH}$-sensitive materials with benzene and their subsequent

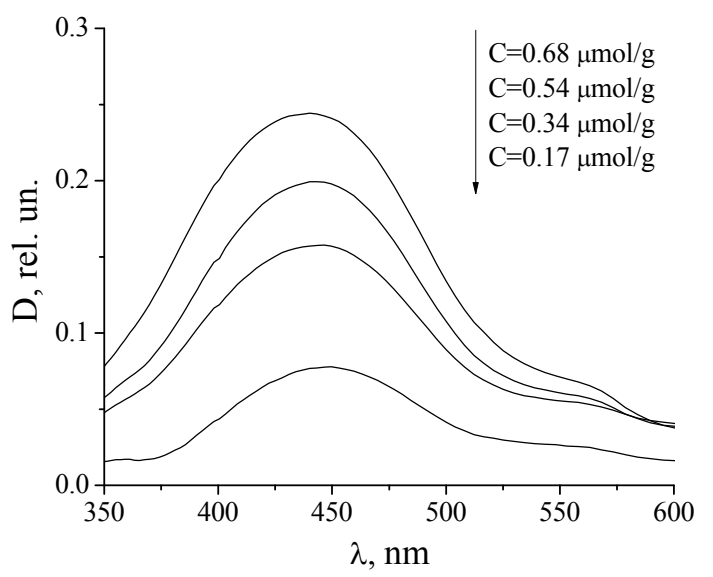

$a$ drying at $100{ }^{\circ} \mathrm{C}$ for $2 \mathrm{~h}$ does not influence the profile of DRUV spectra (Fig. 2). Moreover, reflection maximum belonging to the $n \rightarrow \pi^{*}$ transition of the $-\mathrm{N}=\mathrm{N}-$ group in benzene pretreated organosilicas coincides with that of 3-MR- $-\mathrm{SiO}_{2}$ silica rinsed with buffer solutions (pH 4.8-6.6) and is registered at $468 \mathrm{~cm}^{-1}$.

The DRUV studies of silica materials with deposited dye molecules results in the spectra comparable with those of MR in phosphate buffer solutions and MR chemically immobilized on $\mathrm{NH}_{2}-\mathrm{SiO}_{2}$ (Figs. 1-3). The profiles of the spectra are similar although there are some alterations in the position of their maxima (Figs. 1-3). As can be seen from Fig. $3 a$, the reflection band at $445 \mathrm{~nm}$ is registered in the DRUV spectra of MR deposited on silica surface in content range $0.17-0.68 \mu \mathrm{mol} / \mathrm{g}$. Its position is bathochromically shifted in comparison with the absorption band of MR in phosphate buffer solution with $\mathrm{pH}=6-7$. It can be supposed that non-ionized silanols interact with basic nitrogen of indicator dye, as well as surface 3-aminopropyl groups - with carboxylate functionalities of deposited MR moieties through hydrogen bonds formation and affect the red shift of chromophore band. Increase of deposited MR content up to $22.35 \mu \mathrm{mol} / \mathrm{g}$ causes appearance of intense reflection band near by $415 \mathrm{~nm}$ and the shoulder around $560 \mathrm{~nm}$ (Fig. $3 b$ ). Their positions are close to the corresponding reflections in the transmittance spectra of azobenzene dye at $\mathrm{pH}$ 6-7.

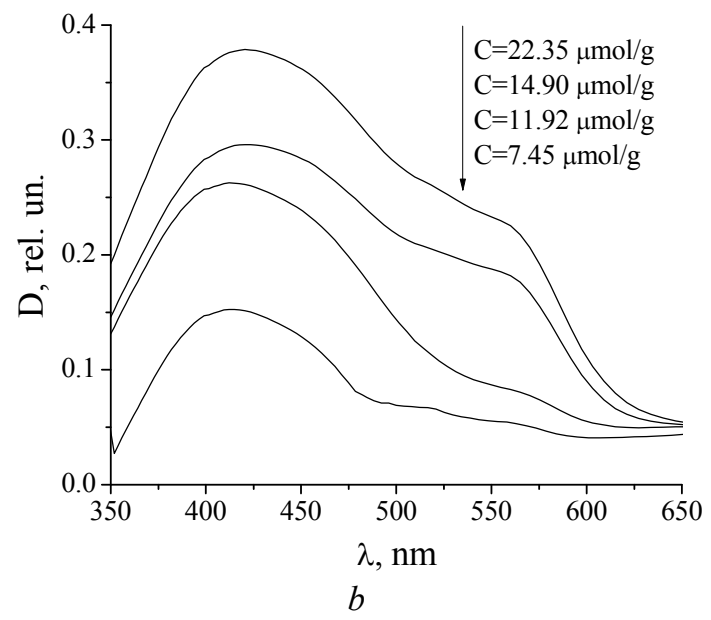

Fig. 3. DRUV spectra of MR deposited on $\mathrm{NH}_{2}-\mathrm{SiO}_{2}$ from benzene solution: ground samples $(a)$, ground samples diluted in a 1:20 ratio with $\mathrm{KBr}$ powder $(b)$ 
In the present work, attempts were made to elucidate influence of MR chemical immobilization on structural parameters of silica carrier, to quantify the content of covalently bonded azobenzene moieties in $\mathrm{MR}-\mathrm{SiO}_{2}$ silicas using DRUV spectral analysis, and to compare with the results of chemical and thermogravimetric analysis.

The isotherms of nitrogen adsorption-desorption on initial and chemically modified silicas belong to type $\mathrm{V}$ according to the IUPAC classification (Fig. 4). Isotherms of this type describe adsorption on the surface of mesoporous sorbents with weak affinity for adsorbate. Intensive rise of isotherm curves is observed at relative pressures above 0.8 . The appearance of the hysteresis loop on the isotherms of parent and chemically modified silica materials indicates the condensation of nitrogen in mesopores. Pore size distribution curves obtained from the desorption branches of the isotherms prove the mesoporous structure of silica materials (Fig. 5). Introduction of 3-aminopropyl as well as MR-containing functional groups in silica surface does not influence noticeably the wide pore size distribution typical for initial silica (Fig. 5). Structural parameters of silica materials calculated from nitrogen adsorption-desorption isotherms are represented in Table 1.
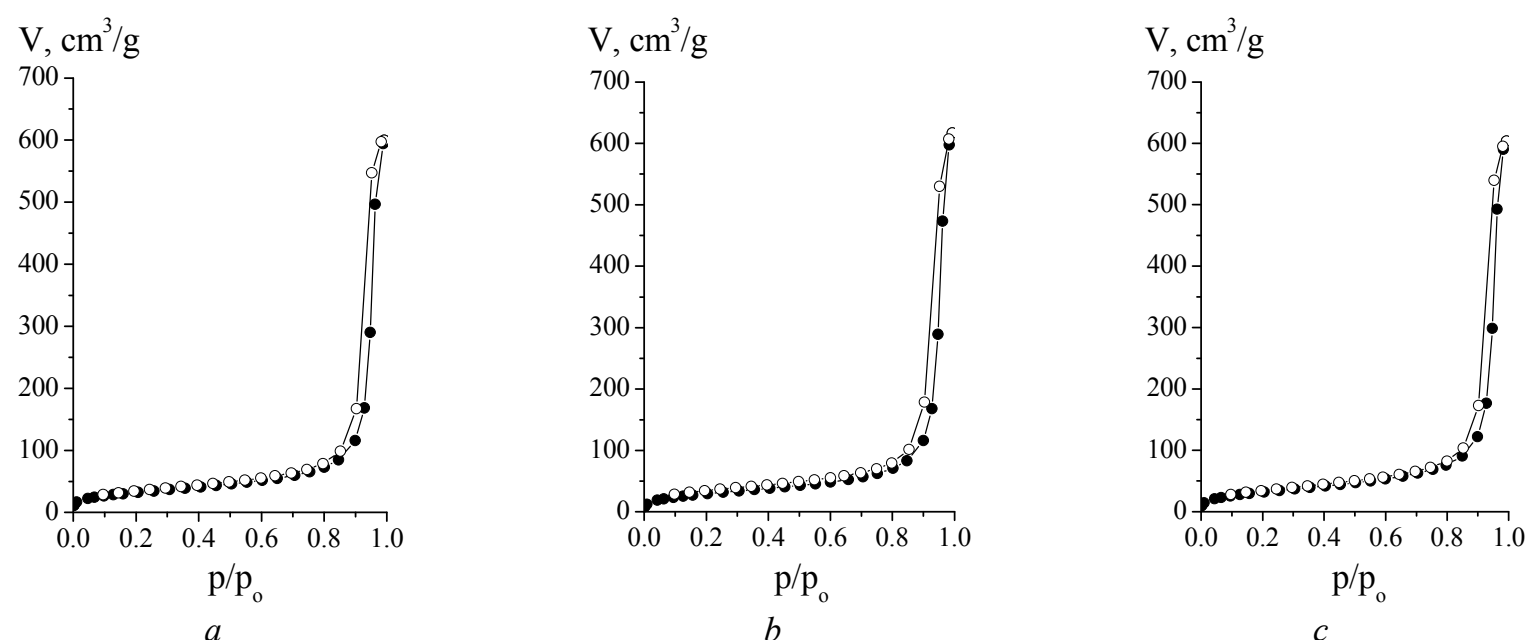

Fig. 4. Isotherms of low-temperature nitrogen adsorption-desorption for initial silica $(a), \mathrm{NH}_{2}-\mathrm{SiO}_{2}(b)$, and $3-\mathrm{MR}-\mathrm{SiO}_{2}(c)$

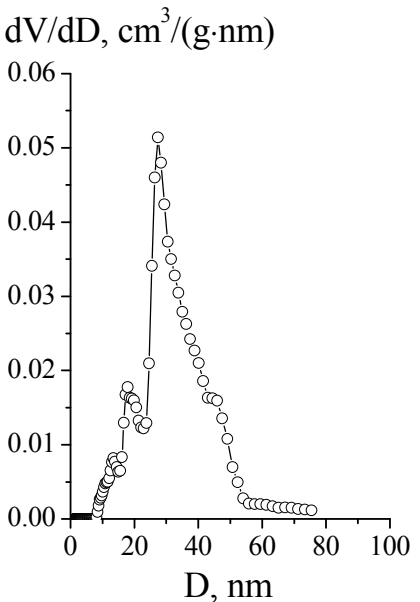

$a$
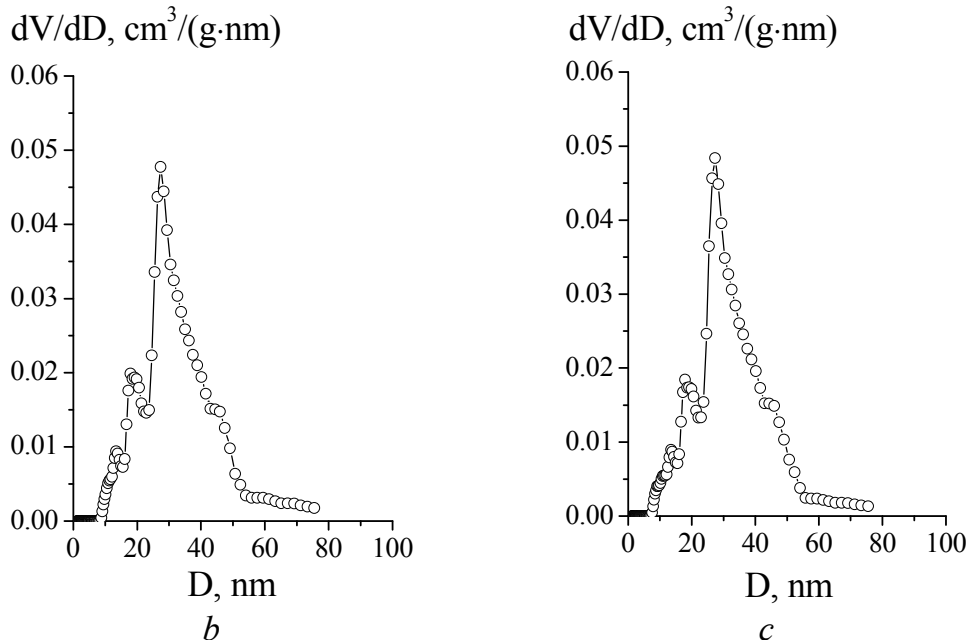

Fig. 5. Pore size distributions for initial silica (a), $\mathrm{NH}_{2}-\mathrm{SiO}_{2}(b)$, and 3-MR- $-\mathrm{SiO}_{2}(c)$ 
Table 1. Parameters of porous structure for silica materials calculated from low-temperature adsorption-desorption of nitrogen

\begin{tabular}{cccc}
\hline Silica & $\boldsymbol{S}_{\text {BET }}, \mathbf{m}^{2} / \mathbf{g}$ & $\boldsymbol{V}, \mathbf{c m}^{\mathbf{3}} / \mathbf{g}$ & $\boldsymbol{D}, \mathbf{n m}$ \\
\hline Initial silica & 141 & 0.93 & 27.4 \\
$\begin{array}{c}\text { Aminopropylsilica } \\
\mathrm{NH}_{2}-\mathrm{SiO}_{2}\end{array}$ & 116 & 0.96 & 27.4 \\
MR-containing silica & & & \\
3-MR-SiO & & 0.94 & 27.4 \\
\hline
\end{tabular}

For the determination of the amount of chemically bonded methyl red by DRUV spectroscopy, calibration curves plotted for a series of standards across a range of dye contents impregnated into aminopropylsilica near its expected values in synthesized organosilicas were used (Figs. 3,6). As particle size and morphology may affect the optical signal, all the reflectance spectra were registered for grounded parent silica materials or diluted with $\mathrm{KBr}$ ones against aminopropylsilica or its mixture with $\mathrm{KBr}$, respectively, as background. Obtained results imply that calibration curves plotted as reflectance of MR impregnated into

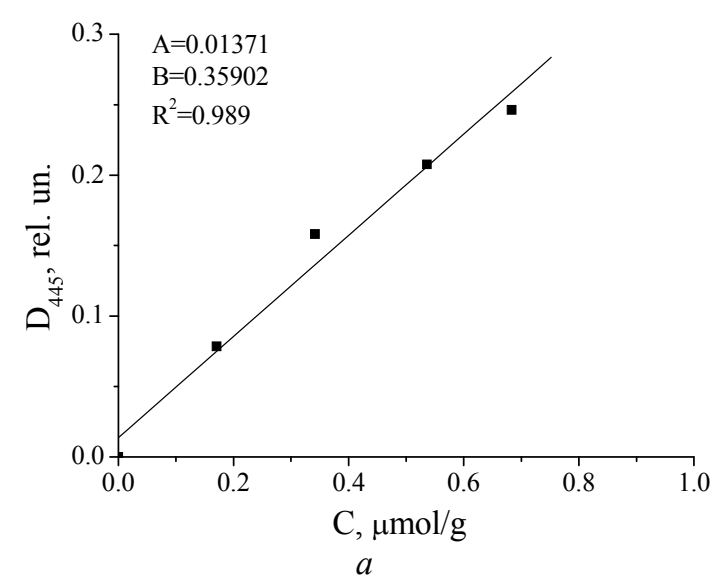

aminopropylsilica against its content show a linear character in both studied regions (Fig. 6). However, position of reflection maxima in the spectra of silica materials with lower content of MR impregnated into $\mathrm{NH}_{2}-\mathrm{SiO}_{2}$ is closer to the reflection maxima in the DRUV spectra of chemically immobilized azobenzene dye. Therefore, determination of the amount of chemically bonded MR by DRUV spectroscopy was realized using calibration curves plotted for a series of silicas with content of impregnated MR in the range $0.17-0.68 \mu \mathrm{mol} / \mathrm{g}$. Obtained results are represented in Table 2.

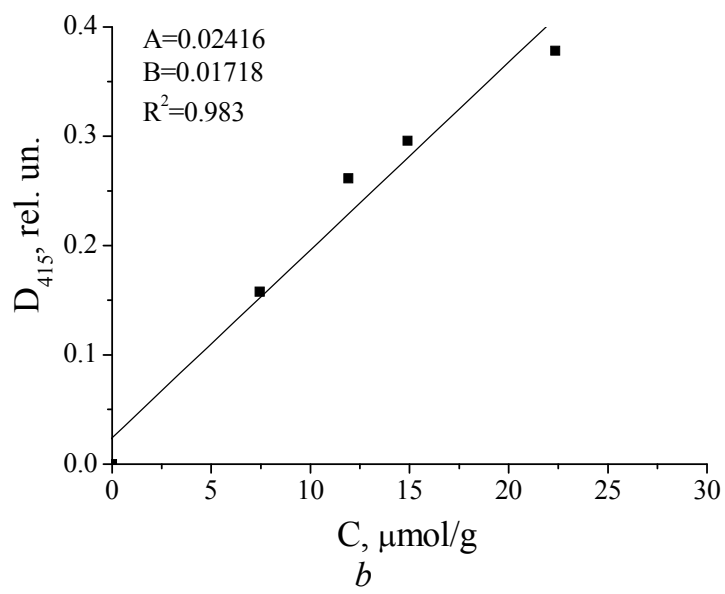

Fig. 6. Calibration curves obtained from DRUV spectra of MR impregnated into $\mathrm{NH}_{2}-\mathrm{SiO}_{2}$ from benzene solution: ground samples $(a)$, ground samples diluted in a 1:20 ratio with $\mathrm{KBr}$ powder $(b)$

Cleavage of grafted MR from the carrier surface was achieved by acid-base hydrolysis of amide bonds in $\mathrm{MR}-\mathrm{SiO}_{2}$ in aqueous medium. This procedure leads to the formation of 3 -aminopropyl groups on silica surface, whereas indicator passes into the solution and its quantity can be determined by transmittance UV-Vis spectroscopy using calibration curve. The results of quantitative chemical analysis of $\mathrm{MR}-\mathrm{SiO}_{2}$ silicas are represented in Table 2.
The thermal stability of synthesized silica materials was characterized by thermogravimetry. As can be seen from Fig. $7 a$, endothermic effect is observed on the curves of differential thermal analysis (DTA) for $\mathrm{NH}_{2}-\mathrm{SiO}_{2}$ and 1-MR-SiO 2 at low temperatures. It is caused by removal of adsorbed water from the surface of organosilicas and proceeds with the mass loss on the curves of thermogravimetric analysis (TG) (Fig. 7 b). Thermal decomposition of organic surface layer of $\mathrm{NH}_{2}-\mathrm{SiO}_{2}$ begins at 
temperatures around $250{ }^{\circ} \mathrm{C}$ and is accompanied by distinct exothermic effect with $T_{\max }=324{ }^{\circ} \mathrm{C}$ on the DTA curve. Two-step mass loss on the TG curve (Fig. $7 b$, curve 4 ) in temperature range of $250-650{ }^{\circ} \mathrm{C}$ belongs to the gradual destruction of 3-aminopropyl groups. Introduction of indicator dye in the structure of aminopropylsilica leads to the substantial changes in the character of thermodestruction (Fig. $7 a$, curve 1). Thermal decomposition of individual MR proceeds with exothermic effect with $T_{\max }=212^{\circ} \mathrm{C}$ [25]. Formation of strong amide bond between indicator dye and silica surface provides increase of its thermal stability

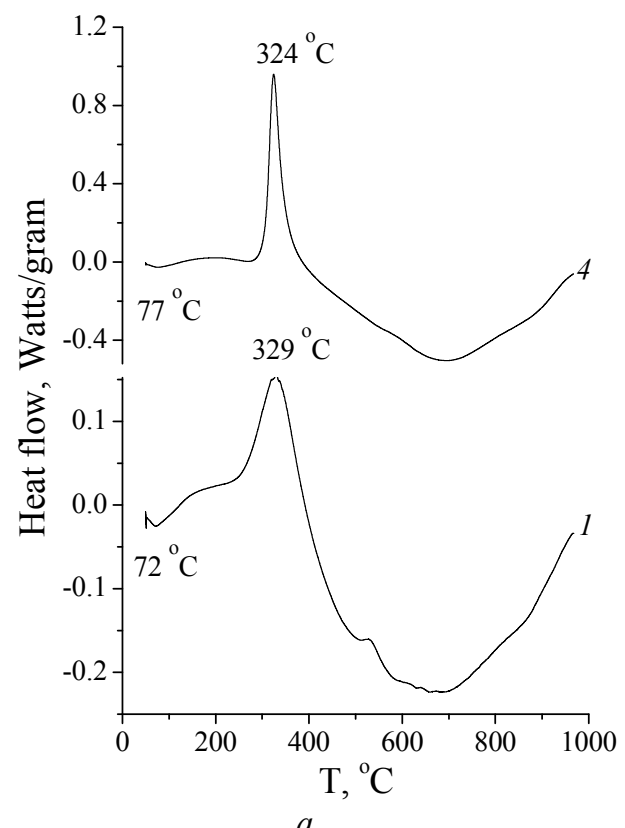

and, as a result, shift of exothermic effect in higher-temperature region. On the DTA curve of 1-MR- $-\mathrm{SiO}_{2}$ we can see the complex exothermic effect with $T_{\max }=329^{\circ} \mathrm{C}$ originated from destruction of chemically immobilized 3-aminopropyl as well as MR-containing groups. Immobilization of $\mathrm{MR}$ on $\mathrm{NH}_{2}-\mathrm{SiO}_{2}$ causes pronounce increase in mass loss for all synthesized silicas (Fig. $7 b$, curves 1-3). The content of grafted MR was determined from the difference in mass loss registered in temperature region $150-650{ }^{\circ} \mathrm{C}$ for $\mathrm{NH}_{2}-\mathrm{SiO}_{2}$ and $\mathrm{MR}-\mathrm{SiO}_{2}$ silicas (Table 2).

Fig. 7. The curves of differential thermal analysis DTA $(a)$ and thermogravimetric analysis TG $(b)$ for $1-\mathrm{MR}_{-} \mathrm{SiO}$ (1), 2-MR- $\mathrm{SiO}_{2}$ (2), 3-MR-SiO 2 (3), and $\mathrm{NH}_{2}-\mathrm{SiO}_{2}$ (4)

Table 2. Content of methyl red chemically immobilized on silica surface

\begin{tabular}{cccc}
\hline \multirow{2}{*}{ Silica } & \multicolumn{3}{c}{ Content of methyl red, mmol/g } \\
\cline { 2 - 4 } & DRUV spectroscopy & chemical analysis & thermogravimetry \\
\hline 1-MR-SiO & 0.026 & 0.024 & 0.027 \\
$2-{\mathrm{MR}-\mathrm{SiO}_{2}}_{3-\mathrm{MR} \mathrm{SiO}_{2}}^{0.020}$ & 0.020 & 0.022 \\
& 0.018 & 0.016 & 0.015 \\
\hline
\end{tabular}

Comparison of the MR content estimated by chemical, DRUV, and thermogravimetric analyses (Table 2) proves good agreement of obtained results. So, it can be stated that DRUV spectroscopy is reliable technique for quantitative determination of indicator dye chemically grafted on silica surface.
Formation of amide linkage between silica surface and indicator dye at chemical immobilization of MR may affect its acid-base properties substantially. It can be expected that higher negative resonance effect of amide bond in comparison with carboxylic group will change the acidity of azo group responsible for the color 
change. To confirm this assumption and evaluate ionization constants of surface functional groups, potentiometric titration of synthesized pH-responsive material was realized using hydrochloric acid as the titrant. Aqueous pHsensitive material suspensions were titrated from $\mathrm{pH}$ near 6.0 when silanol groups of silica surface are partially ionized, whereas residual 3 -aminopropyl groups are not protonated. The experiment was stopped when the $\mathrm{pH}$ was around zero in order to avoid possible hydrolysis of amide bond. The dependence of the suspension $\mathrm{pH}$ on the added volume of titrant is represented in Fig. 8. It has been found that the obtained potentiometric titration curves demonstrate gradual $\mathrm{pH}$ decrease at addition of hydrochloric acid with concentration 0.2 and $0.4 \mathrm{~mol} / \mathrm{l}$. Increase in titrant concentration up to $1 \mathrm{~mol} / \mathrm{l}$ leads to the appearance of barely noticeable inflection. To determine the equivalence point more precisely, a first derivative plot of the titration curve was obtained (Fig. 8).

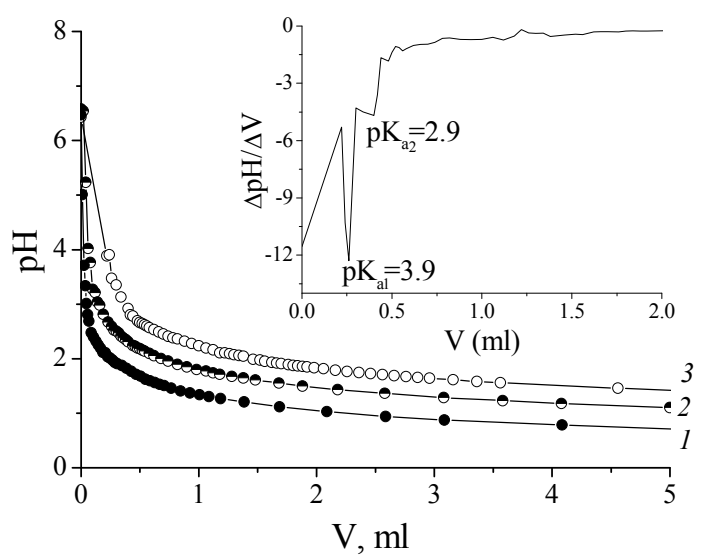

Fig. 8. Potentiometric titration curves of $3-\mathrm{MR}_{-}-\mathrm{SiO}_{2}$ in $1 \mathrm{M} \mathrm{NaCl}$ with $0.2 \mathrm{M}(1), 0.4 \mathrm{M}(2)$ and $1 \mathrm{M} \mathrm{HCl} \mathrm{(3)} \mathrm{at}$ $20{ }^{\circ} \mathrm{C}$. The inserted figure shows the first derivative of the potentiometric titration curve of 3-MR- $\mathrm{SiO}_{2}$ in $1 \mathrm{M} \mathrm{NaCl}$ with $0.2 \mathrm{M} \mathrm{HCl}$ at $20^{\circ} \mathrm{C}$

It can be claimed that obtained values of $\mathrm{p} K_{\mathrm{a}}$ belong to the residual 3-aminopropyl groups of silica surface $\left(\mathrm{p} K_{\mathrm{a} 1}=3.9\right)$ and tertiary amino groups of chemically immobilized azobenzene dye $\left(\mathrm{p} K_{\mathrm{a} 2}=2.9\right)$. So, grafted MR retains the ability for protonation and formation of resonance azonium ion responsible for the colour change at $\mathrm{pH}$ variation. However, the acid-base equilibrium of this process is shifted in comparison with the initial dye.

\section{CONCLUSIONS}

Modification of silica surface with acid-base indicator, methyl red, was realized by chemical assembly method. To estimate parameters of porous structure and chemical composition of synthesized materials, their detailed characterization was carried out using lowtemperature nitrogen adsorption-desorption, quantitative chemical analysis of silica surface, thermogravimetry, diffuse reflectance ultraviolet-visible spectroscopy. The results obtained by transmittance and diffuse reflectance ultraviolet-visible spectroscopy proved that grafted MR retains the ability for protonation of tertiary amino group and formation of resonance azonium ion responsible for the colour change at $\mathrm{pH}$ variation. To evaluate the changes in protolytic properties of indicator dye caused by its chemical immobilization on silica carrier, aqueous potentiometric titration was performed. It has been found that the protonation of surface MR-containing functionalities proceeds at higher $\mathrm{pH}$ values in comparison with individual indicator dye. So, the color change from orange to red for methyl red linked to the silica surface takes place in less acidic solutions compared to individual indicator dye. 


\title{
рН-чутливі матеріали на основі кремнезему з хімічно іммобілізованим метиловим червоним: синтез та протолітичні властивості
}

\author{
Н.В. Роїк, Л.О. Бєлякова, М.О. Дзязько \\ Інститут хімії поверхні ім. О.О. Чуйка Національної академії наук України \\ вул. Генерала Наумова, 17, Київ, 03164, Україна, roik_nadya@ukr.net
}

\begin{abstract}
Мета иієї роботи - вивчення можливості створення гідролітично і хімічно стійких рН-чутливих матеріалів з використанням кремнезему як носія та кислотно-основного індикатора, що змінює забарвлення при варіюванні $\mathrm{pH}$ середовища. Синтез $\mathrm{pH}$-чутливих матеріалів було здійснено иляхом ковалентного зв'язування барвника метиловий червоний з амінопропілкремнеземом у присутності 1,1'-карбонілдиімідазолу як зииваючого агента. Пориста структура, хімічний склад поверхні та протолітичні властивості синтезованих кремнеземних матеріалів охарактеризовано за допомогою низькотемпературної адсорбиіїдесорбиії азоту, кількісного хімічного аналізу, термогравіметрії, електронної спектроскопії дифузного відбиття, рН-метрії. Встановлено, що хімічна іммобілізаиія метилового червоного на поверхні кремнезему не спричиняє суттєвого впливу на пористу структуру вихідного кремнезему. Вміст кислотно-основного індикатора, хімічно іммобілізованого на поверхні кремнезему, визначено шллххом кількісного хімічного аналізу синтезованих матеріалів, а також методами термогравіметрії та електронної спектроскопіі дифузного відбиття в ультрафіолетовій та видимій області. Продемонстровано, що електронна спектроскопія дифузного відбиття може бути надійним методом кількісного визначення індикаторного барвника, хімічно прищепленого до поверхні кремнезему. Доведено, що іммобілізований барвник зберігає здатність до протонування третинної аміногрупи і утворення резонансного іона азонію, який відповідає за зміну кольору метилового червоного. Встановлено, що протонування метилового червоного, хімічно закріпленого на поверхні кремнезему, здійснюється при більщ високих значеннях рН у порівнянні з індивідуальним індикаторним барвником. Тому зміна забарвлення прищепленого метилового червоного відбувається в менш кислих розчинах. Запропонований синтетичний підхід може бути використаний для одержання екологічно чистих $\mathrm{pH}$-чутливих матеріалів багаторазового використання.
\end{abstract}

Ключові слова: метиловий червоний, кремнезем, хімічна іммобілізаиія, $p H$-чутливий матеріал

\section{рН-чувствительные материалы на основе кремнезема с химически иммобилизованным метиловым красным: синтез и протолитические свойства}

\author{
Н.В. Роик, Л.А. Белякова, М.А. Дзязько \\ Институт химии поверхности им. А.А. Чуйко Национальной академии наук Украины \\ ул. Генерала Наумова, 17, Киев, 03164, Украина, roik_nadya@ukr.net
}

Цель настоящей работы - изучение возможности создания гидролитически и химически устойчивых pH-чувствительных материалов с использованием кремнезема в качестве носителя и кислотно-основного индикатора, изменяющего окраску при варьировании $\mathrm{pH}$ среды. Синтез $\mathrm{pH}$-чувствительных материалов был осуществлен путем ковалентного связывания красителя метиловый красный с аминопропилкремнеземом 8 присутствии 1,1'-карбонилдиимидазола в качестве сшивающего агента. Пористая структура, химический состав поверхности и протолитические свойства синтезированных кремнеземных материалов охарактеризовань с помощью низкотемпературной адсорбции-десорбции азота, количественного химического анализа, термогравиметрии, электронной спектроскопии диффузного отражения, $p H$-метрии. Установлено, что химическая иммобилизаџия метилового красного на поверхности кремнезема не оказывает существенного влияния на пористую структуру исходного кремнезема. Содержание кислотно-основного индикатора, химически иммобилизованного на поверхности кремнезема, установлено путем количественного химического анализа синтезированных материалов, а также методами термогравиметрии и электронной спектроскопии диффузного отражения в ультрафиолетовой и видимой области. Продемонстрировано, что электронная спектроскопия диффузного отражения может быть 
надежным методом количественного определения индикаторного красителя, химически привитого к поверхности кремнезема. Доказано, что иммобилизованный краситель сохраняет способность к протонированию третичной аминогруппы и образованию резонансного иона азония, который отвечает за изменение ивета метилового красного. Установлено, что протонирование метилового красного, химически закрепленного на поверхности кремнезема, осуществляется при более высоких значениях рН по сравнению с индивидуальным индикаторным красителем. Поэтому изменение окраски привитого метилового красного происходит в менее кисльх растворах. Предложенный синтетический подход может быть использован для получения экологически чистых рН-чувствительных материалов многократного использования.

Ключевые слова: метиловый красный, кремнезем, химическая иммобилизация, рН-чувствительный материал

\section{REFERENCES}

1. Shamansky L.M., Yang M., Olteanu M., Chronister E.L. A spectroscopic study of the $\mathrm{pH}$ sensor response of fluorescein doped silica and aluminosilica sol-gel glasses. Mater. Lett. 1996. 26(3): 113.

2. Yang L., Saavedra S.S. Chemical sensing using sol-gel derived planar waveguides and indicator phases. Anal. Chem. 1995. 67(8): 1307.

3. Lee J.E., Saavendra S.S. Evanescent sensing in doped sol-gel glass films. Anal. Chim. Acta. 1994 285(3): 265.

4. Kraus S.C., Czolk R., Reichert J., Ache H.J. Optimization of the sol-gel process for the development of optochemical sensors. Sens. Actuators, B. 1993. 15-16(1-3): 199.

5. Bambot S.B., Sipior J., Lakowicz J.R., Rao G. Lifetime-based optical sensing of $\mathrm{pH}$ using resonance energy transfer in sol-gel films. Sens. Actuators, B. 1994. 22(3): 181.

6. Butler T.M., MacCraith B.D., McDonagh C. Leaching in sol-gel-derived silica film for optical pH sensing. J. Non-Cryst. Solids. 1998. 224(3): 249.

7. Lee S.T., Gin J., Nampoori V.P.N., Vallabhan C.P.G., Unnikrishnan N.V., Radhakrishnan P. A sensitive fibre optic pH sensor using multiple sol-gel coatings. Journal of Optics A: Pure and Applied Optics. 2001. 3(5): 355.

8. Wang E., Chow K.-F., Kwan V., Chin T., Wong C., Bocarsly A. Fast and long term optical sensors for pH based on sol-gels. Anal. Chim. Acta. 2003. 495(1-2): 45.

9. Kowada Y., Ozeki T. Preparation of silica-gel film with $\mathrm{pH}$ indicators by the sol-gel method. J. Sol-Gel Sci. Technol. 2005. 33(2): 175 .

10. Wu Z., Jiang Y., Xiang H., You L. Understanding the mechanisms of reaction and release of acid-base indicators entrapped in hybrid gels. J. Non-Cryst. Solids. 2006. 352(52-54): 5498.

11. Capeletti L.B., dos Santos J.H.Z., Moncada E. Quantification of indicator content in silica-based pH solid sensors by diffuse reflectance spectroscopy. Anal. Methods. 2011. 3: 2416.

12. Capeletti L.B., Radtke C., dos Santos J.H.Z., Moncada E., Da Rocha Z.N., Pepe I.M. On the interaction of encapsulated $\mathrm{pH}$ indicator species within a silica matrix produced by three sol-gel routes. Colloids Surf., A. 2011. 392(1): 256.

13. Chauhan S.S., Jasra R.V., Sharma A.L. Dye immobilized mesoporous silica thin film as optical pH sensor. Int. J. Nanosci. 2012. 11(3): 1240001.

14. Zajic J., Traplova L., Matejec V., Pospisilova M., Barton I. Optical pH detection with U-shaped fiber-optic probes and adsorption transducers. Conference Papers in Science. 2015. 2015: 513621.

15. Yamaguchi A., Namekawa M., Kamijo T., Itoh T., Teramae N. Acid-base equilibria inside aminefunctionalized mesoporous silica. Anal. Chem. 2011. 83(8): 2939.

16. Oberg K.I., Hodyss R., Beauchamp J.L. Simple optical sensor for amine vapors based on dyed silica microspheres. Sens. Actuators, B. 2006. 115(1): 79.

17. Nivens D.A., Zhang Y., Angel S.M. A fiber-optic pH sensor prepared using a base-catalyzed organo-silica solgel. Anal. Chim. Acta. 1998. 376(2): 235.

18. Aigner D., Borisov S.M., Fernandez F.J.O., Sanchez J.F.F., Saf R., Klimant I. New fluorescent pH sensors based on covalently linkable PET rhodamines. Talanta. 2012. 99: 194.

19. Tertykh V.A., Belyakova L.A. Chemical reactions with the participation of silica surface. (Kiev: Naukova Dumka, 1991). [in Russian]. 
20. Belyakova L.A., Besarab L.N., Roik N.V., Lyashenko D.Yu., Vlasova N.N., Golovkova L.P., Chuiko A.A. Designing of the centers for adsorption of bile acids on a silica surface. J. Colloid Interface Sci. 2006. 294(1): 11.

21. Tawarah K.M., Abu-Shamleh H.M. A spectrophotometric study of the acid-base equilibria of $o$-methyl red in aqueous solutions. Dyes Pigm. 1991. 17(3): 203.

22. Kolthoff I.M. Acid-base indicators. (New York: The Macmillan Company, 1953).

23. Tobey S.W. The acid dissociation constant of methyl red. J. Chem. Educ. 1958. 35(10): 514.

24. Schirmer R.E. Modern methods of pharmaceutical analysis. V. 1. (Boca Raton: CRC Press, 1982).

25. Tian Y., Wang G., Li F., Evans D.G. Synthesis and thermo-optical stability of methyl red-intercalated Ni-Fe layered double hydroxide material. Mater. Lett. 2007. 61(8-9): 1662. 